\title{
Status of Certain Anthropometric Parameters of Males of Sasaram, India and Its Variation due to Soybean Added Diet
}

\author{
Dina Nath Pandit ${ }^{1}$, Sunil Kumar ${ }^{2}$, Anirudh Singh ${ }^{3}$, Anil Kumar Sinha ${ }^{4}$ \\ ${ }^{1,2,3,4}$ Department of Zoology, Veer Kunwar Singh University, Arrah - 802301 \\ Corresponding Author: Dina Nath Pandit
}

\begin{abstract}
The anthropometric parameters are regarded as sensitive indicators. The core elements of anthropometric parameters are bodyweight, height and body mass index. To assess certain anthropometric features of males of Sasaram in respect to the standards and the variations in these features due to 60 days feeding of soybean added diet was the purpose of the work. Experimental studies indicate that soybean added diet might facilitate loss of bodyweight. All subjects were observed for anthropometric measurements after feeding of routine diet and soybean added diet. The average bodyweight was $63.65 \pm 8.97 \mathrm{~kg}$ of volunteers aged 20-59 years with a height of $162.0+6.0 \mathrm{~cm}$ in controlled condition among 2127 males. The average height of volunteers of $162.0+6.0 \mathrm{~cm}$ was found less than the present standard of the Bihar, India as well as the world. On the other hand, the average of body mass index was $24.88 \pm 3.01 \mathrm{~kg} / \mathrm{m}^{2}$ among the volunteers of the above age group and was found less than the present standard of the world but more than the standard of India. Consumption of soybean added diet was related to a moderately significant decreased weight $(\mathrm{p}<0.01)$ and body mass index. The study helps in establishing the anthropometric features of people of this area in comparison to the standard of the state and the country.
\end{abstract}

Key Words: Bodyweight, Body mass index, Males, Sasaram, Soybean diet.

\section{INTRODUCTION}

It has been well established that anthropometric parameters are the essential tools for determining nutritional status, assessment of the people growth and development for their optimal results ${ }^{(1)}$. The body mass index or BMI seems a measuring scale of general physic and is based on height and weight ratio. The concept of body mass index was devised by Quetelet ${ }^{(2)}$. It provides a reliable metric of body fatness for most people and is used to screen for weight categories ${ }^{(3)}$. Body mass index changes throughout growth and development. It can be used as an indicator for tracking body size throughout the life cycle. Diet plays a very important role in weight loss and gain, and can, thus, directly affect your BMI. Therefore, because of global application to accept identification of particular categories of body mass as a health concern, it has been useful in population-based studies.

While some factors like height are not under one's control, factors like diet and healthy eating can be controlled. If one eats a healthy, balanced diet, they are likely to lose weight and fall in the healthy BMI range ${ }^{(4)}$. Developing countries like India are facing multiple risk and adverse impacts of obesity because of intake of energy dense food, sedentary and passive life style, wanting of facilities of health care and monetary help ${ }^{(5)}$. Soy is obviously selected as an item of diet change or dietary component related to weight loss because of 
its low cholesterol and high protein proportion ${ }^{(6)}$. Cross-sectional studies stress the relation of soy with lower body weight, in addition to many animal studies. Genistein consumption, as for example, was negatively correlated with BMI ${ }^{(7)}$.

One of the agricultural states situated in the eastern part of India is Bihar. It consistently ranks poorly on a number of growth and health-related metrics with almost $10 \%$ of India's population ${ }^{(8)}$. The accessibility of health facilities is very poor and due to dire poverty. The Rohtas district is a part of the Patna Division of Bihar. The administrative headquarters of the district, Sasaram is a place of historical importance and is popularly known as the "bowl of rice. The area is highly fertile and due to this is densely populated with 247,408 individuals. It is known for the production of cement, fertilizers, stone chips, and the quarrying industry.

In this context, the present work is an attempt to assess critically certain anthropometric parameters and their variation due to the effect of soybean added food amongst adult males at Sasaram. The information will support policy-maker, plan of diet preparation and focusing reliable data that is intended for usage.

\section{MATERIALS AND METHODS Collection of Data}

The work was based on information collected from 2127 of males aged 20-59 years from the Sasaram district of Bihar from January 2019 to December 2019. Data were collected by trained technicians of Kumar Janch Ghar (A Pathology and Clinical Centre), Sasaram.

\section{Nutrient Composition}

The nutrient composition of the routine diet was recorded to be $8.46 \pm 8.24 \%$ of nutrients, $1.09 \pm 0.58 \%$ of amino acids, $0.75 \pm 0.41 \%$ and $52.59 \pm 56.47 \mathrm{mg} / \mathrm{kg}$ of minerals. To estimate soy exposure a questionnaire was prepared after a questionnaire of validated soy (Williams et al., 2003). The soybean added diet contained approximately $75.77 \pm 99.43 \mu \mathrm{g} / \mathrm{g}$ (Daidzin: 198.2 and Genistein: 286.1) phytoestrogens while the phytoestrogen content in the routine diet was below the limits of HPLC detection.

\section{Measurement of Anthropometric Parameters}

The height of volunteer was taken thrice standing upright and motionless in the horizontal plane employing a portable stadiometer (Galaxy 214).

The body weight of volunteer wearing light clothing and bare feet was determined also thrice with an electronic digital weighing machine (HD-93).

BMI was calculated by dividing the weight of a volunteer the square of his/her height.

$$
\text { BMI }=\frac{\text { Weight in kilogram }}{\text { Height in } \text { meter }^{2}}
$$

\section{Statistical Analysis}

The data were presented as means and standard deviations. ANOVA was applied to evaluate the effect of soy added diet on BMI applying Excel and SPSS software packages.

\section{OBSERVATIONS AND RESULTS Height, Body Weight and BMI of Control Group}

The average height of 2127 volunteers aged 20-59 years was $1.62+0.06$ $\mathrm{m}$ and showed an inverse and weak relationship $(r=0.674, p>0.05)$ to age.

$$
y=1.635-0.000 x
$$

The mean body weight of $63.65 \pm$ $8.97 \mathrm{~kg}$ ranged from $56.89 \pm 6.60$ to $67.5 \pm$ $12.08 \mathrm{~kg}$ among the volunteers indicated an non-significant positive correlation $(\mathrm{r}=$ $0.779, \mathrm{p}>0.05)$ with age.

$$
\mathrm{y}=\mathbf{5 3 . 8 2}+\mathbf{0 . 2 8 0 x}
$$

The range of BMI was $22.87 \pm 2.43$ to $26.16 \pm 3.14 \mathrm{~kg} / \mathrm{m} 2$ with an average of $24.88 \pm 3.01 \mathrm{~kg} / \mathrm{m} 2$ among the volunteers of the above age group to show an nonsignificant positive correlation $(\mathrm{r}=0.766, \mathrm{p}$ $>0.05$ ) (Table I).

$$
y=21.95+0.083 x
$$


Dina Nath Pandit et.al. Status of certain anthropometric parameters of males of Sasaram, India and its variation due to soybean added diet.

Table 1: Relationship between age and body weight, height and body mass index of males of age group 20-59 years as a control group

\begin{tabular}{|c|c|c|c|c|c|c|c|}
\hline \multirow[t]{2}{*}{$\begin{array}{l}\text { Age Group } \\
\text { (years) }\end{array}$} & \multirow[t]{2}{*}{$\begin{array}{ll}\text { Number } & \text { of } \\
\text { participants } & \end{array}$} & \multicolumn{2}{|l|}{$\begin{array}{l}\text { Height } \\
\text { (meter) }\end{array}$} & \multicolumn{2}{|l|}{$\begin{array}{l}\text { Body Weight } \\
\text { (kg) }\end{array}$} & \multicolumn{2}{|c|}{$\begin{array}{l}\text { Body Mass Index } \\
\left(\mathrm{kg} / \mathrm{m}^{2}\right)\end{array}$} \\
\hline & & Observed & Standard & Observed & Standard* & Observed & Standard \\
\hline $20-29$ & 584 & $\begin{array}{l}1.63 \pm 0.05 \\
{[1.6392]}\end{array}$ & -0.14 & $\begin{array}{l}56.89 \pm 6.60 \\
{[65.9349]}\end{array}$ & $58.6 \pm 5.9$ & $\begin{array}{l}22.87 \pm 2.43 \\
{[24.5482]}\end{array}$ & $\begin{array}{l}\text { Normal } \\
(18.5-23.0)\end{array}$ \\
\hline $30-39$ & 649 & $\begin{array}{l}1.61 \pm 0.06 \\
{[1.6214]}\end{array}$ & -0.16 & $\begin{array}{l}64.85 \pm 8.33 \\
{[63.4936]}\end{array}$ & $55.5 \pm 4.6$ & $\begin{array}{l}25.19 \pm 3.06 \\
{[24.5095]}\end{array}$ & $\begin{array}{l}\text { Obese } \\
(25.0-30.0)\end{array}$ \\
\hline $40-49$ & 670 & $\begin{array}{l}1.62 \pm 0.06 \\
{[1.6037]}\end{array}$ & -0.15 & $\begin{array}{l}67.5 \pm 12.08 \\
{[61.0523]}\end{array}$ & $58.6 \pm 5.9$ & $\begin{array}{l}26.16 \pm 3.14 \\
{[24.4709]}\end{array}$ & $\begin{array}{l}\text { Obese } \\
(25.0-30.0)\end{array}$ \\
\hline 50-59 & 224 & $\begin{array}{l}1.61 \pm 0.05 \\
{[1.5859]}\end{array}$ & -0.16 & $\begin{array}{l}65.37 \pm 8.86 \\
{[58.6109]}\end{array}$ & $55.5 \pm 4.6$ & $\begin{array}{l}25.34 \pm 3.41 \\
{[24.4322]}\end{array}$ & $\begin{array}{l}\text { Obese } \\
(25.0-30.0)\end{array}$ \\
\hline $20-59$ & 2127 & $\begin{array}{l}1.62 \pm 0.06 \\
{[1.61]}\end{array}$ & -0.15 & $\begin{array}{l}63.65 \pm 8.97 \\
{[62.27]}\end{array}$ & $57.1 \pm 1.55$ & $\begin{array}{l}24.88 \pm 3.01 \\
{[24.49]}\end{array}$ & $\begin{array}{l}\text { Overweight } \\
(23.0-24.9)\end{array}$ \\
\hline \multicolumn{3}{|c|}{ ICMR-NIN (2020) recommended average for Indian Males } & $1.77 \mathrm{~m}^{*}$ & & $65 \mathrm{~kg}$ & & $\begin{array}{l}18.5-23.0 \mathrm{~kg} / \mathrm{m}^{2} \\
\text { (Normal) }\end{array}$ \\
\hline
\end{tabular}

\section{Effect of Soybean added Diet on Body Weight}

The bodyweight of 1060 volunteers was found more in the routine diet group but was less in the soybean added diet. A bit hyperbolic variation because of the feeding of soybean added diet was more with the increase of age.

The bodyweight of volunteers of age group 20-59 years after 60 days feeding of routine diet ranged from $57.95 \pm 7.68$ to $70.56 \pm 8.91 \mathrm{~kg}$. The range of bodyweight gave an non-significant positive correlation $(r=0.789, p>0.05)$ to the age.

$$
\mathrm{y}=\mathbf{5 4 . 1 1}+\mathbf{0 . 3 5 9} \mathrm{x}
$$

On the other hand, after 60 days feeding of soybean added diet to 1067 volunteers, the range of body weight was $53.44 \pm 6.96$ to $63.23 \pm 7.85 \mathrm{~kg}$. A nonsignificant direct correlation $(\mathrm{r}=0.708, \mathrm{p}>$ $0.05)$ exists with the age.

$$
\mathbf{y}=\mathbf{5 1 . 4 4}+\mathbf{0 . 2 4 1 x}
$$

ANOVA inferred that both the type of feeding of diet and age group have a moderately significant $(p<0.01)$ effect on the bodyweight of volunteers in both the groups (Table 2).

Table 2: Variation in body mass index of males of age group 20-59 years after 60 days feeding of routine diet and soybean added

\begin{tabular}{|c|c|c|c|c|c|c|c|}
\hline \multirow[t]{3}{*}{$\begin{array}{l}\text { Age Group } \\
\text { (years) }\end{array}$} & \multirow[t]{3}{*}{ Type of diet } & \multirow[t]{3}{*}{$\begin{array}{l}\text { Number of } \\
\text { participants }\end{array}$} & \multirow[t]{3}{*}{$\begin{array}{l}\text { Weight } \\
\text { (kg) }\end{array}$} & \multirow[t]{3}{*}{$\begin{array}{l}\text { Height } \\
\text { (meter) }\end{array}$} & \multicolumn{3}{|c|}{$\begin{array}{l}\text { Body Mass Index } \\
\left(\mathrm{kg} / \mathrm{m}^{2}\right)\end{array}$} \\
\hline & & & & & \multirow[t]{2}{*}{ Observed } & \multicolumn{2}{|c|}{ Standard According to } \\
\hline & & & & & & (ISC, 2008) & (WHO, 2003) \\
\hline \multirow[t]{2}{*}{$20-29$} & Routine diet & 290 & $57.95 \pm 7.68$ & $1.63 \pm 0.05$ & $22.08 \pm 3.06$ & $\begin{array}{l}\text { Normal } \\
(18.5-23.0)\end{array}$ & $\begin{array}{l}\text { Normal } \\
(18.5-23.0)\end{array}$ \\
\hline & Soybean added diet & 294 & $\begin{array}{l}53.44 \pm 6.96 \\
{[-7.78 \%]}\end{array}$ & $\begin{array}{l}1.63 \pm 0.05 \\
{[0 \%]}\end{array}$ & $\begin{array}{l}20.11 \pm 2.78 \\
{[-8.92 \%]}\end{array}$ & $\begin{array}{l}\text { Normal } \\
(18.5-23.0)\end{array}$ & $\begin{array}{l}\text { Normal } \\
(18.5-23.0)\end{array}$ \\
\hline \multirow[t]{2}{*}{$30-39$} & Routine diet & 325 & $68.89 \pm 10.47$ & $1.61 \pm 0.06$ & $26.58 \pm 2.91$ & $\begin{array}{l}\text { Obese } \\
(25.0-30.0)\end{array}$ & $\begin{array}{l}\text { Pre-obese } \\
(25.0-30.0)\end{array}$ \\
\hline & Soybean added diet & 324 & $\begin{array}{l}61.85 \pm 12.61 \\
{[-10.22 \%]}\end{array}$ & $\begin{array}{l}1.61 \pm 0.06 \\
{[0 \%]}\end{array}$ & $\begin{array}{l}23.86 \pm 3.50 \\
{[-10.23 \%]}\end{array}$ & $\begin{array}{l}\text { Overweight } \\
(23.0-24.9)\end{array}$ & $\begin{array}{l}\text { Normal } \\
(23.0-24.9)\end{array}$ \\
\hline \multirow[t]{2}{*}{$40-49$} & Routine diet & 335 & $70.56 \pm 8.91$ & $1.62 \pm 0.06$ & $26.87 \pm 2.47$ & $\begin{array}{l}\text { Obese } \\
(25.0-30.0)\end{array}$ & $\begin{array}{l}\text { Pre-obese } \\
(25.0-30.0)\end{array}$ \\
\hline & Soybean added diet & 335 & $\begin{array}{c}63.23 \pm 7.85 \\
{[-10.39 \%]} \\
\end{array}$ & $\begin{array}{l}1.62 \pm 0.06 \\
{[0 \%]}\end{array}$ & $\begin{array}{c}24.09 \pm 2.18 \\
{[-10.35 \%]}\end{array}$ & $\begin{array}{l}\text { Overweight } \\
(23.0-24.9)\end{array}$ & $\begin{array}{l}\text { Normal } \\
(23.0-24.9)\end{array}$ \\
\hline \multirow[t]{2}{*}{$50-59$} & Routine diet & 110 & $69.37 \pm 10.69$ & $1.61 \pm 0.05$ & $26.76 \pm 4.28$ & $\begin{array}{l}\text { Obese } \\
(25.0-30.0)\end{array}$ & $\begin{array}{l}\text { Pre-obese } \\
(25.0-30.0)\end{array}$ \\
\hline & Soybean added diet & 114 & $\begin{array}{l}61.02 \pm 11.62 \\
{[-12.04 \%]}\end{array}$ & $\begin{array}{l}1.61 \pm 0.05 \\
{[0 \%]}\end{array}$ & $\begin{array}{l}23.54 \pm 4.65 \\
{[-12.03 \%]}\end{array}$ & $\begin{array}{l}\text { Overweight } \\
(23.0-24.9)\end{array}$ & $\begin{array}{l}\text { Normal } \\
(23.0-24.9)\end{array}$ \\
\hline \multirow[t]{3}{*}{$20-59$} & Routine diet & 1060 & $66.69 \pm 9.44$ & $1.618 \pm 0.055$ & $25.57 \pm 3.18$ & $\begin{array}{l}\text { Obese } \\
(25.0-30.0)\end{array}$ & $\begin{array}{l}\text { Pre-obese } \\
(25.0-30.0)\end{array}$ \\
\hline & Soybean added diet & 1067 & $\begin{array}{l}59.88 \pm 10.47 \\
{[-10.21 \%]}\end{array}$ & $\begin{array}{l}1.618 \pm 0.055 \\
{[0 \%]}\end{array}$ & $\begin{array}{l}22.90 \pm 3.278 \\
{[-10.44 \%]}\end{array}$ & $\begin{array}{l}\text { Normal } \\
(18.5-23.0)\end{array}$ & $\begin{array}{l}\text { Normal } \\
(18.5-23.0)\end{array}$ \\
\hline & & & \multicolumn{2}{|c|}{$\begin{array}{l}\text { ANOVA }\left(\mathrm{C}_{\mathrm{df1}}=69.64 * *\right. \\
\left.\mathrm{R}_{\mathrm{df} 3}=39.39 * *\right)\end{array}$} & \multicolumn{3}{|c|}{$\operatorname{ANOVA}\left(\mathrm{C}_{\mathrm{df1}}=60.90^{* *} ; \mathrm{R}_{\mathrm{df} 3}=33.22 * *\right)$} \\
\hline
\end{tabular}
diet 
Dina Nath Pandit et.al. Status of certain anthropometric parameters of males of Sasaram, India and its variation due to soybean added diet.

\section{Effect of Soybean added Diet on BMI}

The BMI of 1060 volunteers was more in routine diet group but was less in the soybean added diet. The hyperbolic variation because of the feeding of soybean added diet was more with an increase of age.

The BMI of volunteers of 20-59 years after feeding of routine diet for 60 days ranged from $22.08 \pm 3.06$ to $26.76 \pm$ $4.28 \mathrm{~kg} / \mathrm{m}^{2}$. The dispersion of body mass index gave a weak relationship $(r=0.793, p$ $>0.05)$ with age.

$$
y=21.99+0.143 x
$$

On the other hand, feeding of soybean fortified diet for 60 days to 1067 volunteers; the dispersion of BMI was 20.11 \pm 2.78 to $23.58 \pm 4.65 \mathrm{~kg} / \mathrm{m}^{2}$. A weak relationship $(\mathrm{r}=0.725, \mathrm{p}>0.05)$ exists with age.

$$
y=20.27+0.105 x
$$

Multivariate analysis inferred that each kind of feeding of diet and volunteers have moderately significant $(p<0.01)$ impact on the BMI of volunteers in each groups (Table 2).

\section{DISCUSSION}

Environmental parameters act as important features dispiriting in fitness and growth of individuals ${ }^{(9)}$. It may be counseled that growth parameters be updated frequently based on the temporal pattern of growth in a population ${ }^{(10)}$. In India, a profane trend in anthropometrical parameters is obvious over last 30-40 years (11). Over the last 4-5 decades, there has been a rise in body mass index in common population. This has resulted in predictions

\begin{tabular}{|c|c|c|c|c|c|c|}
\hline $\begin{array}{l}\text { Population } \\
\text { (by 2019) }\end{array}$ & Height & $\begin{array}{l}\text { Change per decade } \\
\text { (cm) }\end{array}$ & Country / State & $\begin{array}{l}\text { Population } \\
\text { (by 2019) }\end{array}$ & Height & $\begin{array}{l}\text { Change per } \\
\text { decade }(\mathrm{cm})\end{array}$ \\
\hline 139.77 crore & $\begin{array}{l}166.3 \pm 2.585 \\
(157.2-168.6)\end{array}$ & $\begin{array}{l}0.403 \pm .529 \\
(-1.16 \text { to } 1.31)\end{array}$ & Jammu \& Kashmir & 1.25 crore & 168.3 & +1.09 \\
\hline 5547 & 185.6 & - & Meghalaya & 26.5 lakh & 157.2 & -0.57 \\
\hline 27.06 crore & 158.0 & & Bihar & 9.9 crore & 163.8 & +0.40 \\
\hline 767.35 crore & 169.97 & & & & & \\
\hline
\end{tabular}
of a public health catastrophe forecasts.
The height of males ranged from $158.0 \mathrm{~cm}$ in Indonesia to $185.6 \mathrm{~cm}$ in Dinaric Alps with a world average of 169.97 cm (Table: 3). ICMR- NIN ${ }^{(12)}$ has revised the heights for Indian men to $177.0 \mathrm{~cm}$. The average height of a male of Bihar state is $164.6 \mathrm{~cm}$ and increasing with the rate of $0.48 \mathrm{~cm}$ per decade ${ }^{(8)}$. The average height of volunteers of $162.0+6.0 \mathrm{~cm}$ of Sasaram in this work was found less than the present standard of the state, country as well as world. Determination of height not only based on eating patterns, socioeconomic factors and demographic features, but also on genetic structure and environmental conditions. Therefore the change in height seems to be least within a particular group of individuals; on the other hand, body weight of individuals on several biotic and abiotic factors ${ }^{(13)}$.

The ICMR-NIN ${ }^{(12)}$ also revised the average weight for Indian men with regard to age to 20-39 years were $65 \mathrm{~kg}$. Therefore, the mean body weight of $63.65 \pm 8.97 \mathrm{~kg}$ of volunteers of Sasaram was less compared to the latest Indian standard. The average body weight of $66.69+9.44 \mathrm{~kg}$ of volunteers of age-group 20-59 years was found more in the routine diet group but was $59.88+10.47$ $\mathrm{kg}$ and less after 60 days feeding of soybean added diet. A meta-analysis report of $\mathrm{Mu}$ et al., (14) confirmed that certain products of soy significantly $(\mathrm{p}<0.05)$ declined body weight of Asian populations $(-0.37 \mathrm{~kg})$.

An indicator of living standards on nutritional standing may be expressed through the BMI ${ }^{(15)}$ and has been correlated with socioeconomic factors in various developed as well as developing nations ${ }^{(3)}$. WHO expert group (16), proposed BMI based criterion $23.0-24.9$ and $\geq 25 \mathrm{~kg} / \mathrm{m} 2$ respectively for overweight and obese people residing in the Asia-Pacific nations. Men either overweight or obese are a total of $12.6 \%(10.9-20.1 \%)$ in Bihar based on $>25.0 \mathrm{~kg} / \mathrm{m}^{2}$ scale (Table: 4 ). The average 
Dina Nath Pandit et.al. Status of certain anthropometric parameters of males of Sasaram, India and its variation due to soybean added diet.

BMI among the volunteers was of Sasaram. The variation of BMI is thus very $24.88 \pm 3.01 \mathrm{~kg} / \mathrm{m}^{2}$, indicating the high due to variation in weight ${ }^{(17)}$. overweight category of individuals of

\begin{tabular}{|c|c|c|c|c|c|c|c|}
\hline Sl.No. & Classification & $\begin{array}{l}\text { BMI }\left(\mathbf{k g} / \mathbf{m}^{2}\right) \\
\text { (WHO) }\end{array}$ & $\begin{array}{l}\text { BMI } \\
\text { (ISC) }\end{array}$ & SI.No. & Classification & $\begin{array}{l}\text { BMI }\left(\mathbf{k g} / \mathbf{m}^{2}\right) \\
\text { (WHO) }\end{array}$ & $\begin{array}{l}\text { BMI } \\
\left(\mathrm{kg} / \mathrm{m}^{2}\right)(\mathrm{ISC})\end{array}$ \\
\hline 1. & Underweight & $<18.50$ & $<18.50$ & 4. & Pre-obese & $25.00-29.99$ & $24.00-24.99$ \\
\hline & Underweight & $<16.00$ & $<16.00$ & 5. & Obese & $\geq 30.00$ & $\geq 25.00$ \\
\hline & Severe thinness & $16.00-16.99$ & $16.00-16.99$ & & a. Obese Class I & $30.00-34.99$ & $25.00-29.99$ \\
\hline & Mild thinness & $17.00-18.49$ & $17.00-17.49$ & & $\begin{array}{l}\text { b. Obese Class II } \\
\text { (Obese morbidly) }\end{array}$ & $35.00-39.99$ & $30.00-34.99$ \\
\hline 2. & $\begin{array}{l}\text { Normal Range } \\
\text { (Healthy) }\end{array}$ & $18.50-24.99$ & $18.50-22.99$ & & $\begin{array}{l}\text { c. Obese Class III } \\
\text { (Obese morbidly) }\end{array}$ & $\geq 40.00$ & $\geq 35.00$ \\
\hline 3. & Overweight & $\geq 25.00$ & $\geq 23.00$ & & & & \\
\hline
\end{tabular}

\begin{tabular}{|c|c|c|c|c|c|c|c|c|c|}
\hline Country & Rank & $\begin{array}{l}\text { Mean } \\
\text { BMI } \\
\left(\mathrm{kg} / \mathrm{m}^{2}\right)\end{array}$ & $\begin{array}{l}\text { Male } \\
\text { rank }\end{array}$ & $\begin{array}{ll}\text { Male } & \text { mean } \\
\text { BMI } & \\
\left(\mathrm{kg} / \mathrm{m}^{2}\right) & \\
\end{array}$ & Country & Rank & $\begin{array}{l}\text { Mean } \\
\text { BMI } \\
\left(\mathrm{kg} / \mathrm{m}^{2}\right)\end{array}$ & $\begin{array}{l}\text { Male } \\
\text { rank }\end{array}$ & $\begin{array}{ll}\text { Male mean } \\
\text { BMI } \\
\left(\mathrm{kg} / \mathrm{m}^{2}\right)\end{array}$ \\
\hline Nauru & 1 & 32.5 & 1 & 32.1 & Eritrea & 190 & 20.5 & 190 & 20.1 \\
\hline India & 178 & 21.9 & 172 & 21.8 & & & & & \\
\hline
\end{tabular}

The BMI of males ranged from $32.1 \mathrm{~kg} / \mathrm{m}^{2}$ in Nauru to $20.1 \mathrm{~kg} / \mathrm{m}^{2}$ in Eritrea with a world average of $26.1 \mathrm{~kg} / \mathrm{m}^{2}$ (WHO, 16) but $21.8 \mathrm{~kg} / \mathrm{m}^{2}$ in India (Table-5). The average BMI of $25.57+3.18 \mathrm{~kg} / \mathrm{m}^{2}$ of volunteers was more in the routine diet group but was $22.90+3.278 \mathrm{~kg} / \mathrm{m}^{2}$ and less in the soybean added diet. The average BMI of volunteers in this work was found less than the present standard of the world but more than the standard of the country. A meta-analysis report of $\mathrm{Mu}$ et al., (14) confirmed that soy products significantly $(\mathrm{p}<0.05)$ reduced BMI of Asian populations $\left(-0.27 \mathrm{~kg} / \mathrm{m}^{2}\right)$. Furthermore, Yamori ${ }^{(18)}$ observed that feeding of fish in Japan was related to low BMI as soy feeding.

Garrow and Webster ${ }^{(19)}$ explained that by using regression, a BMI of 16.9 in men represents total absence storage of body fat. The present observation indicates that volunteers in both conditions possess fat as their regression was 21.99 and 20.27 respectively.

Because soy intake was related to consumption of vegetable low BMI in the high soy feeding group is also an outcome of healthy lifestyles and feeding behaviours instead of an immediate effect of soy foods. During this context, Maskarinec et al., (20) discovered that eating additional soy foods in active people expected low BMI and low annual weight gain since age 21 for Caucasians and, to a lesser degree, for Japanese. Intake of soy during early life was not related to body mass index at age 21 or throughout adulthood. Moreover, Yamori (18) fish intake in a work in Japan was related to low BMI similar to consumption of soy. An inverse association between soy food intake that remained vital once accounting for age and BMI of men was conjointly investigated by Chavarro et al., (21)

\section{CONCLUSIONS}

The observations infer that males of Sasaram possess less height, less body weight and less BMI compared to ICMRNIN ${ }^{(12)}$ standards. The results also suggest that men consuming more soy foods during active life have comparatively low BMI than other people of the city. The information will support policy-maker, plan of diet preparation and focusing reliable data that is intended for usage.

\section{ACKNOWLEDGEMENT}

We appreciate Head of the Department of Zoology, VKS University, Arrah-802301 for providing necessary laboratory facilities. No funding was received for the work. 
Dina Nath Pandit et.al. Status of certain anthropometric parameters of males of Sasaram, India and its variation due to soybean added diet.

\section{Conflict of Interests}

Authors have no personal, academic, financial, commercial or political competing interests exist.

\section{Financial Support: None}

Ethical Approval: Taken from Ethical Committee of the Organisation, Study centre and Volunteers.

\section{REFERENCES}

1. Chatterjee $S$, Chatterjee $P$. and Bandyopadhyay A. Skin fold thickness, body fat percentage and body mass index in obese and non-obese Indian boys. Asia Pacific Journal of Clinical Nutrition. 2006; 15:232-235.

2. Quetelet LAJ. Royal Netherlands Academy of Arts and Sciences. 17961874. Retrieved 20 July 2015.

3. Gautam RK. Adak DK, Gharami AK. and Datta T. Body mass index in Central India: inter district variation. Anthropologischer Anzeiger. 2006; 64(4):1-15.

4. Afeiche M, Williams PL, Mendiola J, Gaskins AJ, Jørgensen N, Swan .SH. and Chavarro JE. Dairy food intake in relation to semen quality and reproductive hormone levels among physically active young men. Human Reproduction. 2013; 28:2265-75.

5. Ahirwar R. and Mondal PR. Prevalence of obesity in India: A systematic review: Diabetes Metabolic Syndrome. 2019; 13(1):318-21.

doi: 10.1016/j.dsx.2018.08.032.

6. Anderson JW, Fuller J, Patterson K, Blair R. and Tabor A. Soy compared to casein meal replacement shakes with energyrestricted diets for obese women: randomized controlled trial. Metabolism. 2007; 56:280-288.

7. Naaz A, Yellayi S, Zakroczymski MA, Bunick D, Doerge DR. and Lubahn DB. The soy isoflavone genistein decreases adipose deposition in mice. Endocrinology, 2003; 144:3315-20.

8. Ministry of Health and Family WelfareNational Family health Survey-4 (MHFW-NFHS4). State Fact Sheet Bihar.
International Institute of Population Sciences, Mumbai. 2015-2016.

9. Kuczmarski RJ, Ogden CL, Guo SS, Grummer-Strawn LM, Flegal KM. and Mei Z. CDC Growth Charts for the United States: Methods and development. Vital Health Statatistics. 2002; 246:1-190.

10. Cameron N. The methods of auxological anthropometry. In: Falkner F, Tanner JM (eds). Human growth- A comprehensive treatise. III. 2nd ed. New York: Plenum Press, 1986; 3-46.

11. Khadilkar VV, Khadilkar AV, Cole TJ. and Sayyad MJ. Cross-sectional growth curves for height, weight and body mass index for affluent Indian children. Indian Pediatrics. 2009; 46: 477-89.

12. ICMR.-NIN. National Institute of Nutrition Changes Average Weight, Height Measurements for Indian Men and Women. 2020.

13. Lashari SK, Korejo HB. and Memon YM. To determine frequency of etiological factors in short statured patients presenting at an endocrine clinic of a tertiary care hospital. Pakistan Journal of Medical Sciences, 2014; 30(4):858-861. PMCID: PMC4121713.

14. Mu Y, Kou T, Wei B, Lu X, Liu J. and Tian H. (Soy Products Ameliorate Obesity-Related Anthropometric Indicators in Overweight or Obese Asian and Non-Menopausal Women: A MetaAnalysis of Randomized Controlled Trials. Nutrients. 2019; 11:2790. doi:10.3390/nu11112790.

15. Nube M, Asenso-Okyere WK. and Van den Boom G.J.M. Body mass index as an indicator of standard of living in developing countries. European Journal of Clinical Nutrition. 1998; 52:136-144.

16. World Health Organization. International Association of Study of Obesity, International Obesity task Force, The Asia Pacific Perspective, Redefining Obesity and Treatment. 2020.

17. Adak DK, Gautam RK, Bharati S, Gharami AK, Pal M. and Bharati P. Body mass index and chronic energy deficiency of adult males of Central Indian populations. Human Biology, 2006; 78(2):201-18. 
Dina Nath Pandit et.al. Status of certain anthropometric parameters of males of Sasaram, India and its variation due to soybean added diet.

18. Yamori Y. Worldwide epidemic of obesity: hope for Japanese diets. Clinical Experimental and Pharmacological Physiology, 2004; 31(Suppl 2), S2-S4.

19. Garrow JS. and Webster J. Quetelet's index (W/H2) as a measure of fatness. International Journal of Obesity. 1985; 9(2):147Y153.

20. Maskarinec G, Aylward AG, Erber E, Takata Y. and Kolonel LN. Soy Intake is related to a Lower Body Mass Index in Adult Women. European Journal of Nutrition. 2008; 47(3):138-44. doi:10.1007/s00394-008-0707-x.
21. Chavarro JE, Furtado J, Toth TL, Ford J, Keller M, Campos H. and Hauser R. Trans-fatty acid levels in sperm are associated with sperm concentration among men from an infertility clinic. Fertility Sterility. 2011; 95:1794-97.

How to cite this article: Pandit DN, Kumar S, Singh A et.al. Status of certain anthropometric parameters of males of Sasaram, India and its variation due to soybean added diet. Int $J$ Health Sci Res. 2021; 11(4): 313-319. DOI: https://doi.org/10.52403/ijhsr.20210437 